\title{
Effects of heme degradation products on reactivation of latent HIV-1
}

\author{
P. SHANKARAN ${ }^{1}$, M. MADLENAKOVA ${ }^{1,2}$, V. HAJKOVA ${ }^{1,2}$, D. JILICH ${ }^{3,4}$, I. SVOBODOVA $^{5}$, A. HORINEK ${ }^{5,6}$, \\ Y. FUJIKURA ${ }^{1}$, Z. MELKOVA ${ }^{1,2^{*}}$
}

\begin{abstract}
${ }^{1}$ Department of Immunology and Microbiology, $1^{\text {st }}$ Faculty of Medicine, Charles University, Studnickova 7, 12800 Prague 2, Czech Republic; ${ }^{2 B I O C E V, ~ B i o t e c h n o l o g y ~ a n d ~ B i o m e d i c i n e ~ C e n t e r ~ o f ~ t h e ~ A c a d e m y ~ o f ~ S c i e n c e s ~ a n d ~ C h a r l e s ~ U n i v e r s i t y ~ i n ~ V e s t e c, ~}$ Průmyslová 595, 25250 Vestec, Czech Republic; ${ }^{3}$ AIDS Center Prague, Na Bulovce Hospital, Prague, Czech Republic; ${ }^{4}$ Department of Infectious and Tropical Diseases, $1^{\text {st }}$ Faculty of Medicine, Charles University, Na Bulovce Hospital, Praha, Czech Republic; ${ }^{5}$ Institute of Biology and Medical Genetics, $1^{\text {st }}$ Faculty of Medicine, Charles University and General University Hospital, Prague, Czech Republic; ${ }^{6}$ Third Department of Medicine, $1^{\text {st }}$ Faculty of Medicine, Charles University and General University Hospital, Prague, Czech Republic
\end{abstract}

Received June 14, 2016; revised August 22, 2016; accepted January 8, 2017

\begin{abstract}
Summary. - Human immunodeficiency virus (HIV-1) infection can be currently controlled by combined antiretroviral therapy, but a sterilizing cure is not achievable as this therapy does not target persistent HIV-1 in latent reservoirs. Therefore, different latency reversal agents are intensively explored in various models. We have previously observed that heme arginate, a drug approved for human use, reveals a strong synergism with PKC inducers in reactivation of the latent provirus. Heme is physiologically decomposed by heme oxygenases into 3 degradation products: iron $\left(\mathrm{Fe}^{2+}\right)$, carbon monoxide (CO) and biliverdin which is further converted to bilirubin by biliverdin reductase. In this paper, we have studied the effects of individual heme-degradation products on latent HIV-1 reactivation in ACH-2 cells harboring integrated HIV-1 provirus and in $\mathrm{H} 12$ clone of Jurkat cells harboring HIV-minivirus expressing EGFP. We employed addition of ascorbate to generate $\mathrm{Fe}^{2+}$, resulting in increased expression of both HIV-1 p24 Ag and EGFP in PMA-stimulated ACH-2 and H12 cells, respectively, as characterized on RNA and protein levels. On the other hand, addition of a CO-donor or bilirubin decreased the p24 expression. The reactivation of latent HIV-1 by iron or heme arginate was inhibited by antioxidant Nacetyl cysteine, or by an iron chelator desferrioxamine, suggesting that the effects were mediated by iron- or heme-induced redox stress. Finally, we demonstrated the stimulatory effects of heme arginate and PMA on HIV-1 expression in peripheral blood mononuclear cells of HIV-infected patients cultured ex vivo. These results may constitute a new direction in the latent HIV-1 reactivation and therapy.
\end{abstract}

Keywords: HIV-1 reactivation; iron; heme arginate; carbon monoxide; bilirubin; redox stress

*Corresponding author. E-mail: zmelk@LF1.cuni.cz; phone: +42022496-8507.

Abbreviations: AIDS = acquired immune deficiency syndrome; cART = combined anti-retroviral therapy; $\mathrm{CO}=$ carbon monoxide; CORM-A1 = carbon monoxide releasing molecule-A1; $\mathrm{DFO}=$ desferrioxamine; $\mathrm{EGFP}=$ enhanced green fluorescent protein; GAPDH = glyceraldehyde 3-phosphate dehydrogenase; GSH = glutathione; $\mathrm{HA}=$ heme arginate; HIV-1 = human immunodeficiency virus- 1 ; HO-1 = heme oxygenase-1; LTR = long terminal repeat; $\mathrm{NAC}=\mathrm{N}$-acetyl cysteine; PBMC's = peripheral blood mononuclear cells; $\mathrm{PKC}=$ protein kinase $\mathrm{C} ; \mathrm{PMA}=$ phorbol myristate acetate; ROS $=$ reactive oxygen species; RNS $=$ reactive nitrogen species

\section{Introduction}

HIV/AIDS pathogenesis inherently involves increased generation of reactive oxygen and nitrogen species (ROS, RNS) mediated by pro-inflammatory cytokines. An increased redox stress with decreased levels of glutathione (GSH) were found already in early stages of HIV infection (Pace and Leaf, 1995). Redox stress regulates signal transduction by activating redox-sensitive transcription factors like NF- $\kappa \mathrm{B}$ and NFAT, as well as chromatin remodeling, namely by inhibiting histone deacetylases (Kennedy et al., 2012; Pan- 
tano et al., 2006; Rahman et al., 2004). HIV-1 LTR includes multiple upstream DNA regulatory elements that serve as binding sites for cellular transcription initiation factors and facilitate NF- $\kappa \mathrm{B}$ and NFAT binding. ROS are involved in the reactivation of HIV from latent reservoirs through posttranslational activation of NF- $\kappa B$ (Pyo et al., 2008). While activated, NF- $\kappa \mathrm{B}$ facilitates HIV gene expression by directing recruitment of the histone acetyltransferases to the HIV-1 LTR (Gatignol, 2007). Iron and ascorbate-mediated redox stress affects methylation status of the promoters of genes involved in the redox stress response (Yara et al., 2013).

We have previously demonstrated in human T-cell lines that Normosang (heme arginate; HA), a hemin derivative approved for human use in treatment of acute porphyria, reactivated the latent provirus by itself or in synergy with PKC inducers like phorbol myristate acetate (PMA), TNF- $\alpha$, prostratin or bryostatin 1 (Shankaran et al., 2011; unpublished data). HA also induced expression of heme oxygenase 1 (HO-1) and inhibition of this enzyme increased the provirus reactivation. Antioxidant $\mathrm{N}$-acetyl cysteine (NAC), precursor of GSH, inhibited the provirus reactivation, suggesting that the reactivation was mediated by ROS (Shankaran et al., 2011).

Heme is an efficient inhibitor of reverse transcriptase (Argyris et al., 2001; Levere et al., 1991; Shankaran et al., 2011), while its derivative hemin stimulates expression of various genes, especially HO-1 (Mense and Zhang, 2006). Free heme is toxic due to its ability to catalyze Fenton reaction generating hydroxyl radicals, highly reactive ROS (Shibahara, 2003). Heme from hemoglobin of aged erythrocytes is physiologically degraded by HO-1 in spleen, but the excess of heme and its derivatives stimulates $\mathrm{HO}-1$ expression ubiquitously (Sheftel et al., 2007; Soe-Lin et al., 2008). HO-1 breaks down heme into iron $\left(\mathrm{Fe}^{2+}\right)$, carbon monoxide $(\mathrm{CO})$, and biliverdin that is consequently reduced to bilirubin by the action of biliverdin reductase. $\mathrm{Fe}^{2+}$ might induce a short-term prooxidative state, while $\mathrm{CO}$ and especially the redox cycle bilirubin/biliverdin/biliverdin reductase act as antioxidants. In general, HO- 1 is considered an antioxidant enzyme with immunomodulatory properties (Otterbein et al., 2003).

In this paper, we have studied the effects of heme degradation products on PMA-induced reactivation of latent HIV-1 when added individually to latently infected T-cell lines. Further, we assessed the effects of antioxidant NAC and iron chelator desferrioxamine (DFO) and verified the stimulatory effects of heme arginate and PMA in PBMC's of $\mathrm{HIV}+$ patients' on combined antiretroviral therapy (cART) cultured ex vivo.

\section{Materials and Methods}

Chemicals. All the media and growth supplements were purchased from Thermo Scientific (USA) or PAA Laboratories GmbH
(Austria). Other chemicals used, including PMA, ferric nitrate, ascorbic acid, CORM-A1, bilirubin, desferrioxamine mesylate salt (DFO) and NAC were purchased from Sigma-Aldrich (Germany) unless otherwise specified. HA (Normosang) was purchased from Orphan Europe (France). The chemicals for RNA and DNA isolation, PCR and real-time PCR were purchased from Top-Bio (Czech Republic), for ddPCR from Bio-Rad (USA), primers and probes from IDT (Belgium) and Life Technologies (USA). TURBO DNAfree kit, Ambion, was from Life Technologies.

Cell lines, primary cells and their treatment. Human T-cell line $\mathrm{ACH}-2$ harboring an integrated HIV-1 provirus (clone \#4; Clouse et al., 1989), their parental cell line A3.01, and the H12 clone of Jurkat cells latently infected with a "mini-virus" containing the HIV-1 LTR-Tat-IRES-EGFP-LTR (Blazkova et al., 2009; Jordan et al., 2003; Shankaran et al., 2011), were grown in RPMI 1640 supplemented with $10 \%$ fetal bovine serum, $2 \mathrm{mmol} / \mathrm{l}$ glutamine, 12.5 $\mathrm{mmol} / \mathrm{l}$ Hepes, and antibiotics (penicillin $1 \times 10^{5} \mathrm{U} / \mathrm{l}$, streptomycin $100 \mathrm{mg} / \mathrm{l} ; 10 \% \mathrm{FBS}-\mathrm{RPMI}$ ). The cells were plated at final concentration of $0.5 \times 10^{6} \mathrm{cells} / \mathrm{ml} /$ well in $10 \%$ FBS-RPMI and then treated with iron $(10 \mu \mathrm{mol} / \mathrm{l})$ and ascorbate $(0.25 \mathrm{mmol} / \mathrm{l}$ in ACH-2 cells; 0.25, 0.5, 1 and $2 \mathrm{mmol} / \mathrm{l}$ in A3.01 and $\mathrm{H} 12$ cells; Hermes-Lima et al., 2000; Zhang et al., 2008) or with heme arginate $(2.5 \mu \mathrm{l} / \mathrm{ml})$, followed by PMA $(0.5 \mathrm{ng} / \mathrm{ml})$; in certain experiments, the cells were pre-treated with additional compounds as specified. The cells were collected after $24 \mathrm{~h}$ (ACH-2 cells) or $48 \mathrm{~h}$ (A3.01 and H12 cells). Stock solutions of PMA and bilirubin were prepared in DMSO and freshly diluted in culture medium to 20x working solutions. Other working solutions were freshly prepared as follows: $100 \mathrm{x}$ $\mathrm{Fe}^{3+}(1 \mathrm{mmol} / \mathrm{l} \mathrm{FeNO}$ in $50 \mathrm{mmol} / \mathrm{l} \mathrm{Hepes} \mathrm{pH}=8$ and $20 \mathrm{mmol} / \mathrm{l}$ EDTA), 100x ascorbate ( $25 \mathrm{mmol} / \mathrm{l}$ ascorbic acid in $\left.\mathrm{H}_{2} \mathrm{O}\right), 100 \mathrm{x}$ CORM-A1 (5 mmol/l CORM-A1 in $\left.\mathrm{H}_{2} \mathrm{O}\right), 20 x$ NAC (100 mmol/l in RPMI 1640), 100x DFO (12.5 mmol/l in $\left.\mathrm{H}_{2} \mathrm{O}\right)$. The compounds were added at final concentrations specified in each experiment. PBMC's of HIV-infected patients on cART with undetectable viremia ( $<50$ copies $/ \mathrm{ml}$ ) were isolated by Ficoll gradient centrifugation (Histopaq, Sigma-Aldrich), differential blood count was determined by Advia 60 hematology system (Bayer Healthcare, USA) and PBMC's were resuspended at final concentration of $5 \mathrm{x}$ $10^{6}$ lymphocytes $/ \mathrm{ml}$ in $10 \%$ FBS-RPMI. PBMC's were plated at 1 $\mathrm{ml} /$ well in a 24 -well plate and subjected to treatment with $2.5 \mu \mathrm{l}$ of $\mathrm{HA} / \mathrm{ml}$ and different concentrations of PMA for $18 \mathrm{~h}$.

Western blot analysis. Cells were collected after $24 \mathrm{~h}$ of incubation, lysed in Laemmli reducing sample buffer, boiled and analyzed by SDS-PAGE and western blotting as previously described (Harlow, 1988; Laemmli, 1970; Shankaran et al., 2011), using chemiluminescence (West Femto, Thermo Scientific). The cell lysates were resolved on a $12 \%$ SDS-PAGE and transferred to a PVDF membrane (Hybond, Bio-Rad). HIV-1 p24 was detected using a mouse monoclonal antibody ND-1 (dilution 1:500; Exbio, Czech Republic) and a peroxidase-conjugated goat anti-mouse IgG (dilution 1:20,000; Sigma Co., USA). $\beta$-actin was detected using a rabbit polyclonal antibody (dilution 1:10,000; Abcam, UK) and a peroxidase-conjugated goat anti-rabbit IgG (dilution 1:20,000, MP Biomedicals-Cappel, 
USA). The chemiluminescence was recorded using ChemiDoc MP system (Bio-Rad) and the densitometry analysis was performed with ImageLab software version 5.0 (Bio-Rad).

Flow cytometry analysis. Flow cytometer Canto II (Becton Dickinson, USA) equipped with 3 lasers emitting at 488, 405 and $633 \mathrm{~nm}$, and with 8 detectors was used. Flow cytometry measurements and subsequent analyzes of the data were performed using the Diva 6 software (Becton Dickinson). EGFP fluorescence was determined in FL1 (detecting at 515-545 nm) and expressed as the arithmetic mean of green fluorescence of green cell population $\mathrm{x}$ percentage of green cells. The results of each experiment performed in duplicate were then normalized to untreated cells (100\%); the graphs represent mean and standard error of mean (S.E.M.) of 3-8 experiments. Live and apoptotic cells were distinguished based on their size and granulosity (FSC-A x SSC-A) and \% of apoptotic cells was calculated (Shankaran et al., 2011).

RNA isolation and quantification. RNA was isolated using RNA Blue reagent by precipitation of the aqueous phase according to the manufacturer's protocol (Top-Bio); RNA was solubilized in nuclease- and protease-free molecular biology grade water (Sigma-Aldrich) with the addition of RiboLock RNase inhibitor (Thermo Scientific; final concentration $1 \mathrm{U} / \mu \mathrm{l}$ ) and stored in $-80^{\circ} \mathrm{C}$ for further use. The concentration and purity of RNA was determined by measuring the absorbance at 260 and $280 \mathrm{~nm}$ using UV spectrophotometer Eppendorf BioSpectrometer (Eppendorff AG, Germany). The RNA isolated from ACH-2 cells was then treated with TURBO DNase (TURBO DNA-free kit, Ambion, Life Technologies) to remove contaminant genomic DNA according to the manufacturer's protocol. For HIV+ PBMC's, $18 \mu \mathrm{l}$ of RNA (out of total $20 \mu \mathrm{l}$ ) were treated with $6 \mathrm{U}$ of TURBO DNase; final volume after inactivation was $26 \mu \mathrm{l}$.

Quantification of HIV-1 RNA by droplet digital PCR. Absolute quantification of the HIV-1 RNA expressed in ACH-2 cells was performed using the QX100 droplet digital PCR system (Bio-Rad) and One-Step RT ddPCR kit for probes (Bio-Rad) according to the manufacturer's protocol. Twenty $\mu$ l of the reaction mixture consisted of $10 \mu \mathrm{l}$ of $2 \mathrm{x}$ One-step RT ddPCR super mix, $0.8 \mu \mathrm{l}$ of $25 \mathrm{mmol} / \mathrm{l}$ manganese acetate, 0.5 or $5 \mathrm{ng}$ of DNase-treated RNA and primers and probes for HIV Gag or human GAPDH. Primers and probes used: HIV-1 Gag-forward primer GAG1 (5'-TCAGCCCAGAAGTAATACCCATGT-3') and reverse primer GAG2 (5'-CACTGTGTTTAGCATGGTGTTT-3'), final concentration $200 \mathrm{nmol} / \mathrm{l}$ each, probe GAG3 (FAM-5'-ATTATCAGAAG GAGCCACCCCACAAGA-3'-BHQ1), final concentration 250 nmol/l (Kiselinova et al., 2014; Pasternak et al., 2008); human GAPDH-1x primer-probe Hs02758991_g1 VIC-MGB labelled (Life Technologies). The droplets were generated using the QX100 droplet generator (Bio-Rad) by mixing $70 \mu$ of droplet generation oil for probes (Bio-Rad) with $20 \mu \mathrm{l}$ of ddPCR reaction mixture and PCR amplification was performed on the T100 thermal cycler (Bio-Rad). The thermal cycling conditions were as follows: reverse transcription at $60^{\circ} \mathrm{C}$ for $30 \mathrm{~min}, 95^{\circ} \mathrm{C}$ for $5 \mathrm{~min}, 40$ cycles consisting of denaturation at $94^{\circ} \mathrm{C}$ for $30 \mathrm{~s}$ and annealing/extension at $60^{\circ} \mathrm{C}$ for $60 \mathrm{~s}$, followed by $10 \mathrm{~min}$ at $98^{\circ} \mathrm{C}$. The amplified droplets were read by the QX100 droplet reader (Bio-Rad) and the data were analyzed by QuantaSoft analysis software 1.6.6.0320 (BioRad). Copies of Gag RNA were standardized to human GAPDH as a reference gene.

Quantification of HIV-1 RNA by real-time PCR. RNA isolated from cultured and stimulated PBMC's of HIV-infected patients treated with cART was used for detection of cell-associated HIV-1 RNA using semi-nested 2-step RT-qPCR adapted from previous papers (Kiselinova et al., 2014; Pasternak et al., 2008). Sixteen $\mu \mathrm{l}$ of DNase-treated RNA were used for reverse transcription in a final volume of $40 \mu \mathrm{l}$ using random hexamer primers (Premium Reverse Transcriptase, Thermo Scientific). Then, $20 \mu \mathrm{l}$ of cDNA were amplified in a total volume of $100 \mu \mathrm{l}$ using GAG1 and SK431 primers (final concentration $250 \mathrm{nmol} / \mathrm{l}$ each; SK431 sequence: 5'-TGCTATGTCAGTTCCCCTTGGTTCTCT-3'; Pasternak et al., 2008) and $0.05 \mathrm{U} / \mu \mathrm{l}$ of Blood Taq DNA polymerase (Top-Bio) in $1 \mathrm{x}$ PCR Blue buffer (Top-Bio) containing $2 \mathrm{mmol} / \mathrm{l} \mathrm{MgCl}_{2}$. The thermal cycling conditions were as follows: initial denaturation at $95^{\circ} \mathrm{C}$ for $5 \mathrm{~min}, 15$ cycles consisting of denaturation at $94^{\circ} \mathrm{C}$ for $30 \mathrm{~s}$, annealing at $55^{\circ} \mathrm{C}$ for $30 \mathrm{~s}$, and extension at $72^{\circ} \mathrm{C}$ for 60 $\mathrm{s}$, followed by terminal extension at $72^{\circ} \mathrm{C}$ for $10 \mathrm{~min}$ using the Mastercycler gradient (Eppendorf AG). Finally, $10 \mu \mathrm{l}$ of the first PCR product were used in duplicate for real-time PCR in a total volume of $50 \mu \mathrm{l}$ containing GAG1 and GAG2 primers, GAG3 probe (final concentration $200 \mathrm{nmol} / \mathrm{l}$ each; GAG3 sequence: FAM-5'-ATTATCAGAAGGAGCCACCCCACAAGA-3'-TAMRA; Pasternak et al., 2008), and 1x qPCR Blue buffer (Top-Bio) using the Applied Biosystems 7300 Real-time PCR system (Applied Biosystems, USA) and the universal cycling conditions. Four $\mu$ l of the first PCR product were used for quantification of a reference gene in a $20 \mu \mathrm{l}$ reaction also in duplicate. Four $\mu \mathrm{l}$ of DNase-treated RNA were used for a no-RT control and further processed in the way analogous to cDNA. The mean of technical duplicates was used for relative quantification of HIV Gag compared to GAPDH. Changes in expression of 10 additional house-keeping genes in healthy donors PBMCs after the individual treatments were determined using Real-time PCR kit for Human reference genes (Generi Biotech, Czech Republic).

Statistical analysis. Results are presented as means \pm S.E.M. (standard error of mean). The data were analyzed and graphically represented using GraphPad Prism 5.04 software. Statistical significance of differences between control and different treatments within each group were determined using a two-sample two-tailed unpaired Student's $t$-test with Welch's correction. Equality of variances was tested with F-test.

\section{Results}

First, we aimed to determine the effects of iron-mediated redox stress on reactivation of the latent $\mathrm{HIV}-1$ in $\mathrm{ACH}-2$ cells harboring an integrated HIV-1 provirus. Since $\mathrm{Fe}^{2+}$ is quickly 
(a)
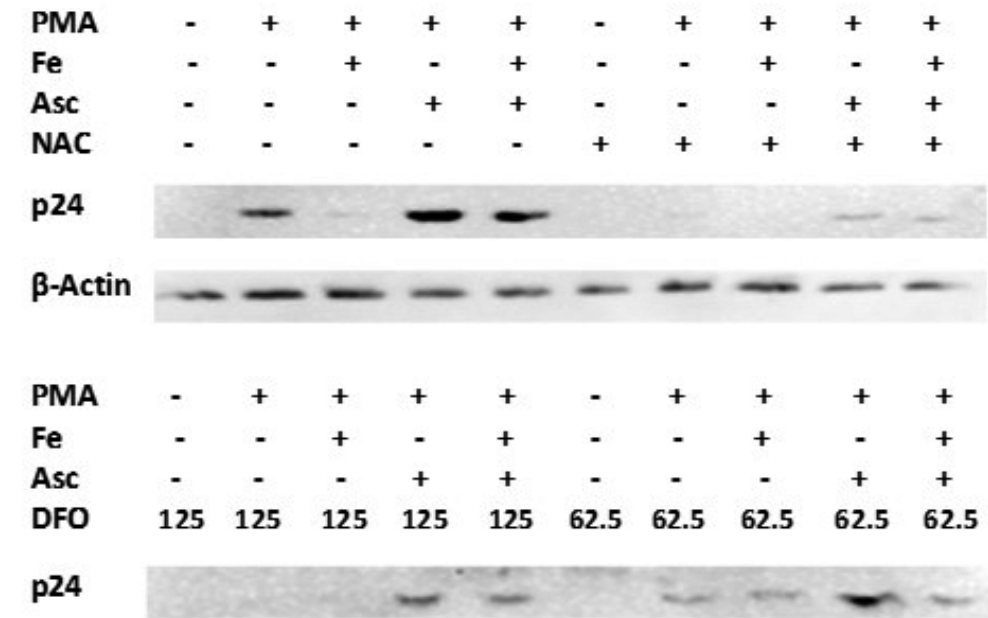

B-Actin

(b)

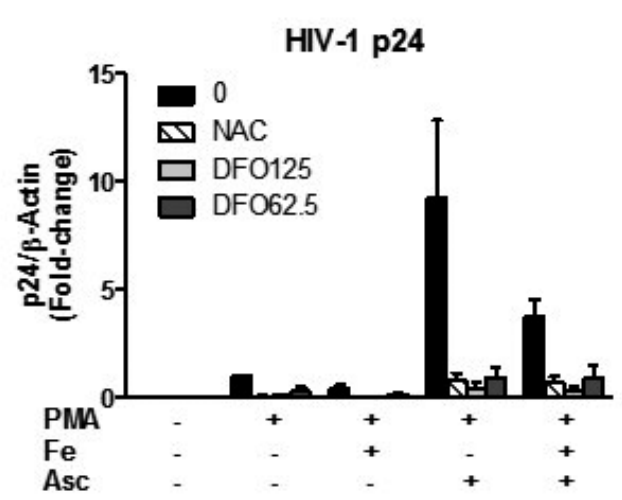

(d)

PMA-

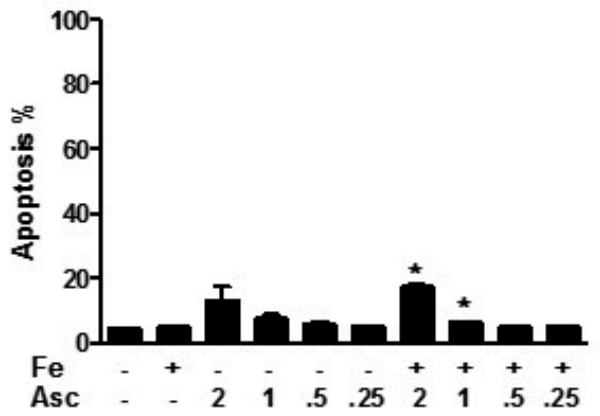

(c)

c)

\section{HV-1 Gag mRNA}

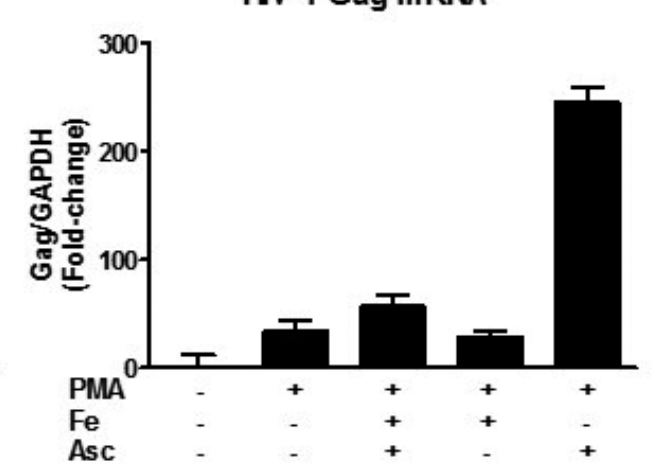

PMA+

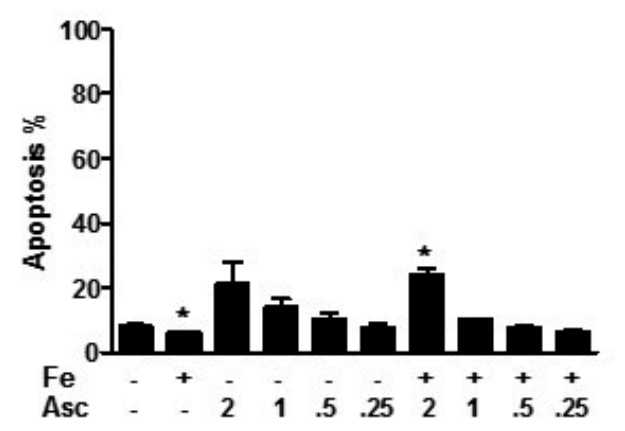

Fig. 1

Effect of iron and ascorbate on PMA-stimulated reactivation of the latent HIV-1

$\mathrm{ACH}-2$ cells pre-treated with $5 \mathrm{mmol} / \mathrm{l} \mathrm{N}$-Acetyl cysteine (NAC) or with 125 and $62.5 \mu \mathrm{mol} / \mathrm{l}$ desferrioxamine (DFO) for $4 \mathrm{~h}$, and treated with $10 \mu \mathrm{mol} / \mathrm{l}$ ferric nitrate (Fe), $0.25 \mathrm{mmol} / \mathrm{l}$ ascorbate (Asc), and $0.5 \mathrm{ng} / \mathrm{ml}$ PMA for $24 \mathrm{~h}$. (a) Western blot analysis of HIV-1 p24 antigen. (b) Digital quantification of the western blots presented in panel (a). (c) Droplet digital PCR (ddPCR) analysis of HIV-1 RNA. (d) Flow cytometric analysis of apoptosis in A3.01 cells, the parental cell line of ACH-2 cells. ${ }^{*}$ Increase is statistically significant when compared to control in each group $(\mathrm{p}<0.05)$. 
(a)

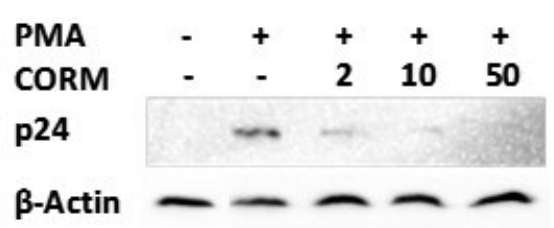

(b)

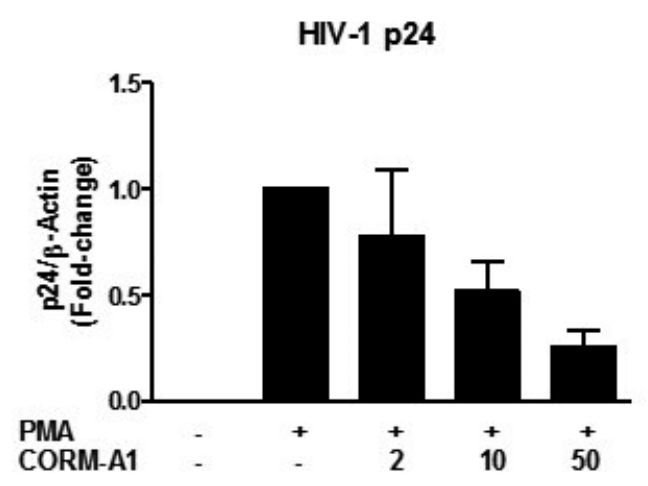

(c)

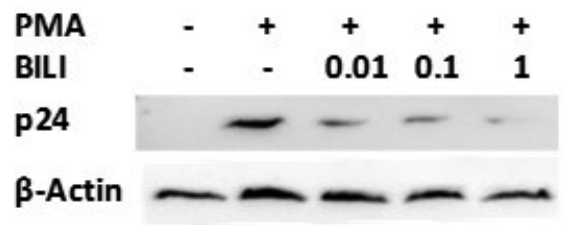

(d)

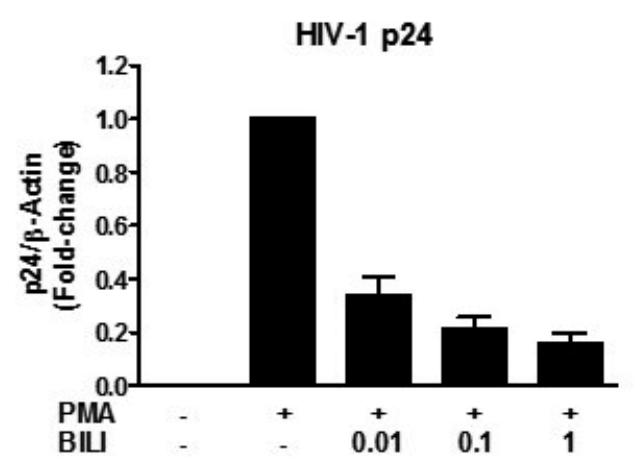

Fig. 2

Carbon monoxide and bilirubin dose-dependently inhibit PMA-stimulated reactivation of the latent HIV-1 ACH-2 cells pre-treated with CORM-A1 (2, 10 and $50 \mu \mathrm{mol} / \mathrm{l})$ for $5 \mathrm{~min}$ or with bilirubin $(0.01,0.1$ and $1 \mu \mathrm{mol} / \mathrm{l})$ for $6 \mathrm{~h}$, and treated with $0.5 \mathrm{ng} / \mathrm{ml} \mathrm{PMA}$ for $24 \mathrm{~h}(\mathbf{a}, \mathbf{c})$ Western blot analysis of HIV-1 p24 antigen. (b, d) Quantification of the western blots presented in panel (a, c), respectively.

oxidized to $\mathrm{Fe}^{3+}$ in the aqueous environment, we employed ascorbate to generate $\mathrm{Fe}^{2+}$ in our system (Hermes-Lima et al., 2000; Zhang et al., 2008). We have treated unstimulated or PMA-stimulated ACH-2 cells with $\mathrm{Fe}^{3+}$, ascorbate and with a combination of $\mathrm{Fe}^{3+}$ and ascorbate. In unstimulated cells, none of the treatments induced p24 expression as detected by western blot analysis and chemiluminescence, recorded and analyzed digitally by the ChemiDoc system. In the PMAstimulated cells, $\mathrm{Fe}^{3+}$ alone decreased the PMA-stimulated p24 levels, while addition of ascorbate with $\mathrm{Fe}^{3+}$ reversed inhibition by $\mathrm{Fe}^{3+}$ due to generation of $\mathrm{Fe}^{2+}$ (Fig. 1 a,b); furthermore, ascorbate with PMA revealed the strongest stimulatory effects. All the stimulatory effects on p24 expression were inhibited by pretreatment of the cells with an antioxidant NAC, precursor of GSH, or with an iron chelator desferrioxamine. These results suggest involvement of free radicals and/or iron in the reactivation of the latent HIV-1 by these compounds, including ascorbate. Interestingly, the effect of $\mathrm{Fe}^{3+}$ on PMA- and ascorbate/PMA-stimulated p24 expression was inhibitory in a way similar to NAC. Thus, $\mathrm{Fe}^{3+}$ alone appears to reveal final antioxidant effects in this system.

In order to further characterize the mechanism of iron and ascorbate action in ACH-2 cells, we have quantified levels of HIV-1 mRNA using 1-step RT-ddPCR. PMA alone increased background Gag mRNA levels 34-times, while addition of ascorbate or addition of iron with ascorbate increased the PMA-stimulated levels about 6- and 2-times more, respectively (Fig. 1c). Again, $\mathrm{Fe}^{3+}$ alone inhibited PMA-stimulated p24 expression.

In addition, we have used a parental cell line of ACH-2 cells, A3.01, to determine effects of the individual treatments on induction of apoptosis using flow cytometry and changes in their size and granulosity (Fig. 1d). PMA treatment increased the background apoptosis about twice, while addition of 2 and $1 \mathrm{mmol} / \mathrm{l}$ ascorbate alone and with iron increased percentage of apoptosis 2-4-times more in both unstimulated and PMA-stimulated cells. Importantly, $0.25 \mathrm{mmol} / \mathrm{l}$ ascorbate that was used in ACH-2 cells did not induce any increase of apoptosis.

The other two degradation products of heme arginate are $\mathrm{CO}$ and biliverdin that is converted to bilirubin by the action of biliverdin reductase. We have used a $\mathrm{CO}$-donor CORM-A1 to characterize the effects of $\mathrm{CO}$ and addition of bilirubin to PMA-stimulated ACH-2 cells. As shown in Fig. 2, increasing concentrations of both CORM-A1 and bilirubin dose-dependently decreased the levels of PMA-stimulated p24 levels. We have also tested the effects of biliverdin, but it did not reveal any appreciable effects (data not shown). 
(a)
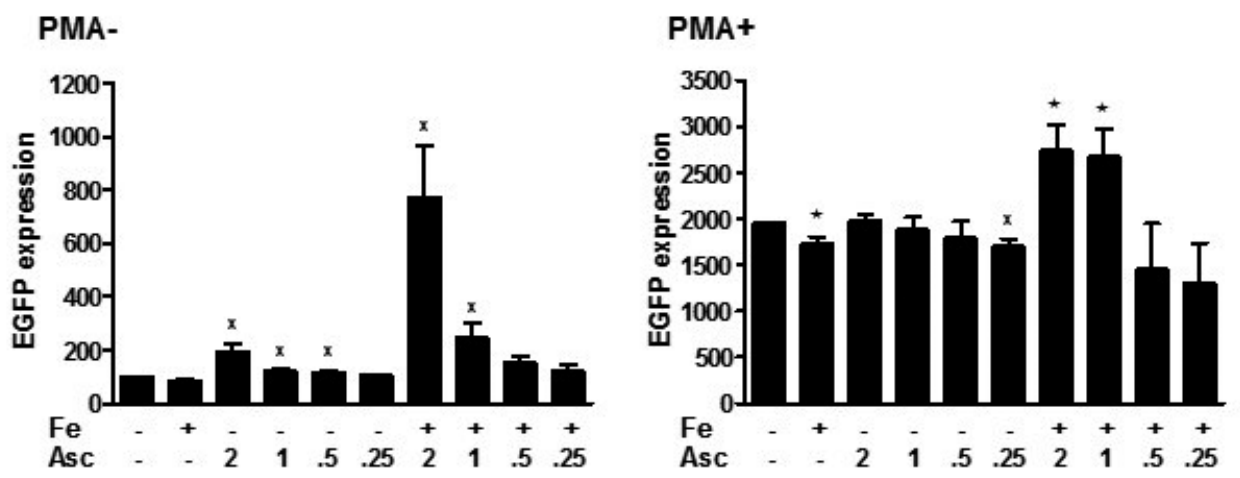

(b)
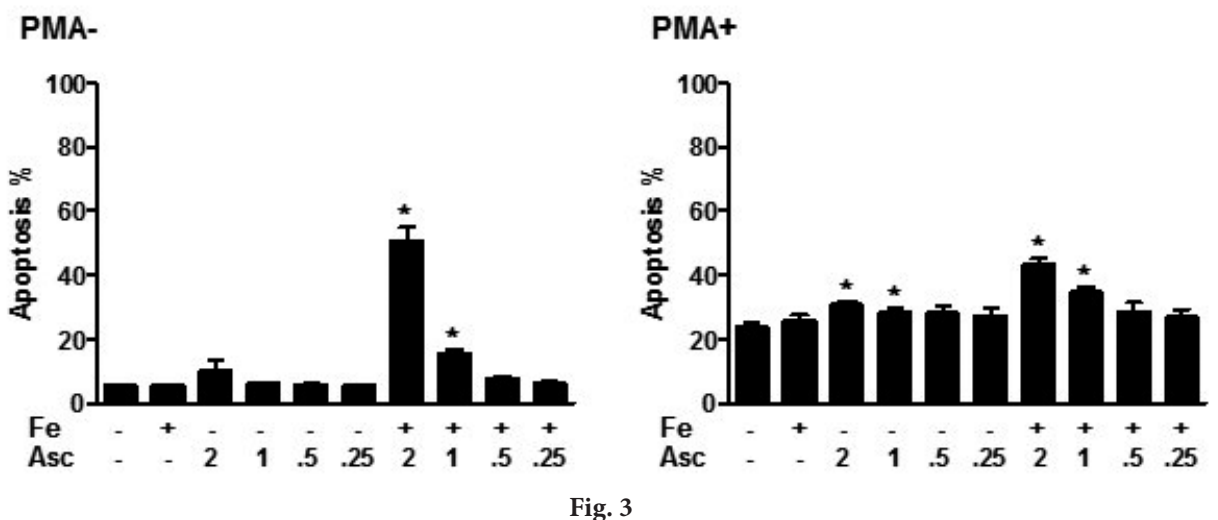

Flow cytometric analysis of EGFP expression

H12 cells treated with $10 \mu \mathrm{mol} / \mathrm{l}$ ferric nitrate (Fe), 2, 1, $0.5 \mathrm{or} 0.25 \mathrm{mmol} / \mathrm{l}$ ascorbate (Asc), and $0.5 \mathrm{ng} / \mathrm{ml}$ PMA for $48 \mathrm{~h}$. (a) Flow cytometric analysis of EGFP expression. (b) Percentage of apoptosis. ${ }^{x, *}$ Increase is statistically significant when compared to control in each group ( $p<0.1,0.05$, respectively).

Additionally, we used the H12 clone of Jurkat cells harboring a latent HIV-1 "mini-virus" expressing EGFP under control of HIV-1 LTR (Shankaran et al., 2011; Jordan et al., 2003). This clone was previously shown to possess an increased methylation of the HIV-1 LTR (Blazkova et al., 2009) and revealed similar responses to HA administration as ACH- 2 cells, except that HA alone, in the absence of PMA, induced EGFP expression also (Shankaran et al., 2011). The combination of iron and ascorbate stimulated EGFP expression both with and without PMA, as determined by flow cytometry, while higher concentrations of ascorbate alone induced EGFP expression also in the unstimulated $\mathrm{H} 12$ cells (Fig. 3a). In other concentrations, including $0.25 \mathrm{mmol} / \mathrm{l}$ that was used in ACH-2 cells, ascorbate did not induce any reactivation. Further, we have determined the percentage of apoptosis induced by the individual treatments in these cells (Fig. 3b). PMA treatment increased the background apoptosis about 5-times, while percentage of apoptosis induced by the individual treatments seemed to reveal a similar pattern as EGFP expression. Then, we tested the effects of CORM-A1 and bilirubin in H12 cells. CORM-A1 increased the levels of EGFP expression in PMA-stimulated $\mathrm{H} 12$ cells while pretreatment with bilirubin did not seem to affect EGFP expression (data not shown). On the other hand, percentage of apoptosis was not affected either by CORM-A1 or bilirubin (around 5 and 25\% in unstimulated and PMAstimulated cells, respectively).

Previously, we have demonstrated a synergistic effect of heme arginate and PMA on reactivation of the latent HIV-1 in ACH-2 cells that was inhibited by the antioxidant NAC (Shankaran et al., 2011). In order to determine the role of iron in the HA-mediated effects, we have now pre-treated the ACH-2 cells with DFO before addition of HA and PMA. As shown in Fig. 4 (a,b) DFO decreased HA- and PMAmediated reactivation of latent $\mathrm{HIV}-1$ as characterized by levels of p24 antigen and western blot analysis. Of note, DFO 
(a)

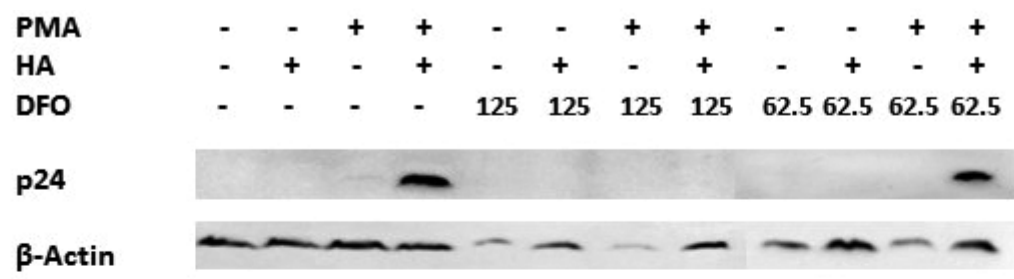

(b)

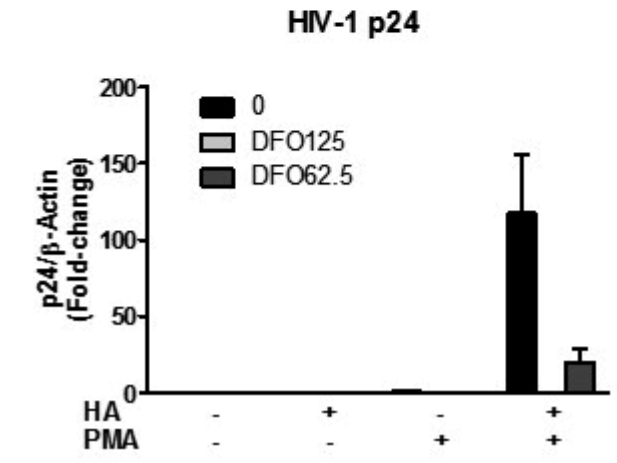

(c)
HN-1 Gag mRNA

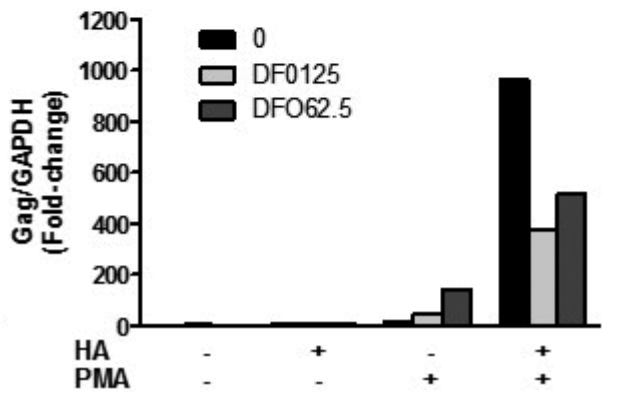

Fig. 4

Iron chelator prevents hem arginate- and PMA-stimulated reactivation of the latent HIV-1

ACH-2 cells pre-treated with 125 and $62.5 \mu \mathrm{mol} / \mathrm{l} \mathrm{DFO}$ for $4 \mathrm{~h}$, and treated with $2.5 \mu \mathrm{l}$ of heme arginate $/ \mathrm{ml}$ and $0.5 \mathrm{ng} / \mathrm{ml}$ PMA for $24 \mathrm{~h}$ (a) Western blot analysis of HIV-1 p24 antigen. (b) Quantification of the western blots presented in panel (a). (c) ddPCR analysis of HIV-1 RNA.

(a)

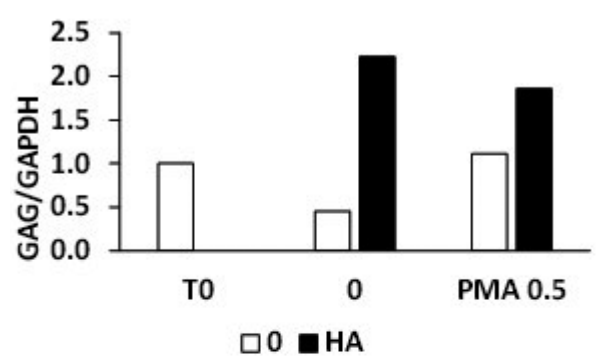

(c)

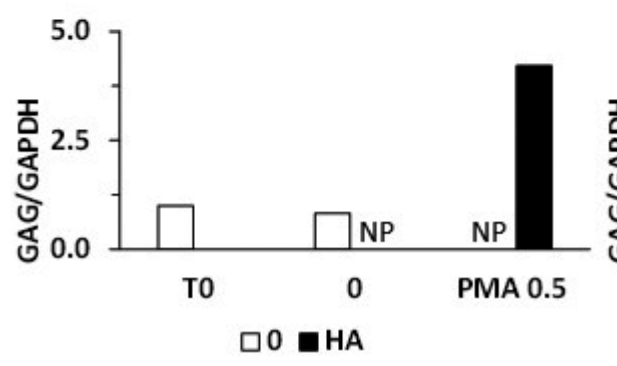

(b)

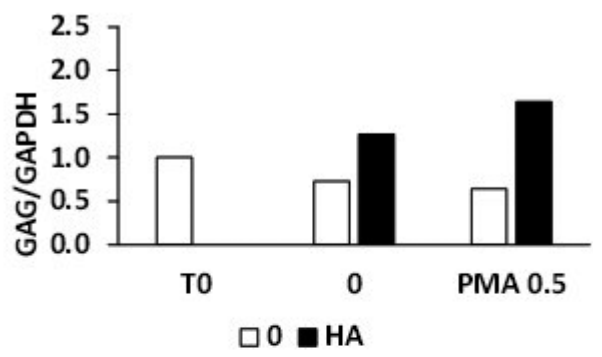

(d)

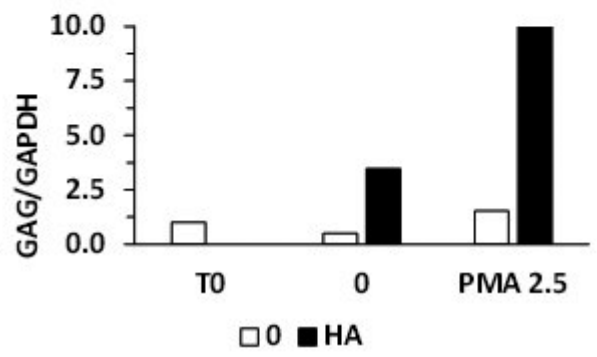

Fig. 5

Heme arginate stimulates HIV-1 expression in human HIV+ PBMC's ex vivo

HIV+ human PBMC's treated with $2.5 \mu \mathrm{l}$ of heme arginate/ml and 0.5 or $2.5 \mathrm{ng} / \mathrm{ml}$ PMA for 18 h. (a,b,c,d) Fold-changes in Gag/GAPDH mRNA levels in PBMC's of 4 aviremic HIV + patients on cART. T0 $=$ time $0,0=$ no treatment, $\mathrm{HA}=$ heme arginate $2.5 \mu \mathrm{l} / \mathrm{ml}$, PMA 0.5 or $2.5 \mathrm{ng} / \mathrm{ml}, \mathrm{NP}=$ not performed. 
decreased also the levels of control $\beta$-actin in the absence of HA in these experiments. Further, we have determined the levels of HIV-1 mRNA using 1-step RT-ddPCR (Fig. 4c). As expected, DFO also decreased the levels of HA- and PMA-stimulated levels of HIV-1 mRNA, indicating the role of iron in PMA- and HA-mediated effects.

The results presented above were performed in cell lines which reveal different mutations and clonal bias. ACH-2 cells are known to have a mutation in the TAR region affecting the Tat-mediated transactivation (Emiliani et al., 1996; Venkatachari et al., 2015), while the expression of the latent provirus in different Jurkat clones is dependent on their integration site (Jordan et al., 2001). Therefore, to validate the effects of HA and PMA on reactivation of the latent HIV-1, we decided to determine the effects of HA and PMA in primary cells isolated from the peripheral blood of HIV-infected patients on cART with undetectable plasma virus load. In the first approach, we have intentionally used PBMC's, as the wider spectrum of cell types is closer to the situation in vivo. As shown in Fig. 5, cell-associated HIV-1 RNA Gag characterized by a semi-nested 2-step RT-qPCR could be detected in all the samples at the time of isolation and went down during the $18 \mathrm{~h}$-incubation ex vivo (based on relative quantification to GAPDH). PMA added at low concentrations somewhat increased the levels of HIV-1 RNA compared to untreated samples. HA alone increased the levels of HIV-1 RNA compared to untreated samples (1.7-4.5-fold), while HA synergized with PMA (2-12-fold increase compared to PMA-untreated samples) similarly as in ACH-2 cells. In these experiments, HIV-1 RNA levels were quantified relatively to GAPDH. In additional experiments, we have determined the effects of these treatments on 10 other house-keeping genes, with changes in expression of GAPDH and $\beta-2$ microglobulin being the smallest and comparable. Nevertheless, their expression was increased by PMA and HA with PMA, affecting the relative changes in HIV-1 RNA levels.

\section{Discussion}

In summary, our results clearly point to the importance of iron and heme metabolism and their dysregulation in pathogenesis of HIV/AIDS. Further, the stimulatory effects of ascorbate warrant for a cautious use of antioxidants, vitamins and other food additives that could affect the redox state of iron.

Previously published results indicated that a longer pretreatment with ascorbate suppressed the induction of HIV reactivation in latently infected T-cell lines (Harakeh and Jariwalla, 1997). However in our experiments, ascorbate added shortly before PMA stimulated latent HIV-1 reactivation in both ACH-2 and $\mathrm{H} 12$ cells; these effects could be

\section{HEME ARGINATE ACTION}

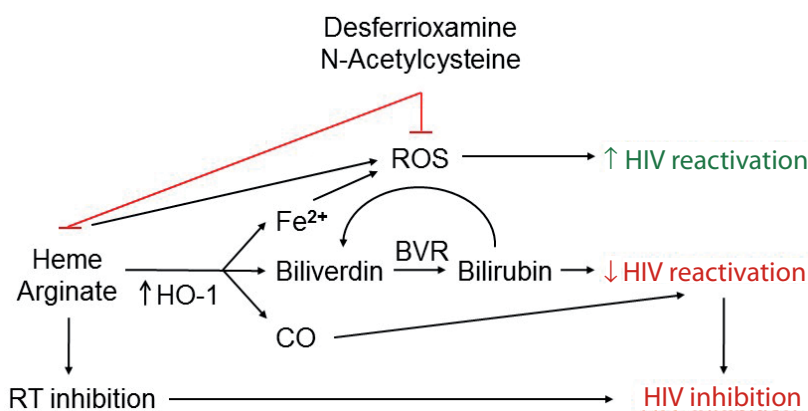

Fig. 6

Scheme of action of heme arginate in ACH-2 cells

Heme inhibits reverse transcription, leading to HIV-1 inhibition. Heme is decomposed by the action of $\mathrm{HO}-1$ into $\mathrm{Fe}^{2+}$, $\mathrm{CO}$ and biliverdin that is further converted to bilirubin by biliverdin reductase. Heme- and ironmediated Fenton reaction generates reactive oxygen species (ROS), leading to reactivation of the latent HIV-1; these processes can be inhibited by the antioxidant N-Acetyl cysteine or iron chelator desferrioxamine. CO and bilirubin inhibit reactivation of the latent HIV-1.

attributed to a double faced character of ascorbate that can act as an anti- or pro-oxidant, depending on its concentration (Best, 2014). Further, the stimulatory effects of ascorbate but also those of PMA were inhibited by DFO, suggesting involvement of iron in these processes. In addition to direct effects of DFO on iron chelation, the inhibition by DFO might be explained also by previously described inhibitory effects of DFO on activation of NF- $\kappa \mathrm{B}$, the redox-sensitive transcription factor involved in both PMA signaling and HIV-1 reactivation (Holden et al., 2008; Sappey et al., 1995). On the other hand, addition of $\mathrm{Fe}^{3+}$, similarly to NAC, was inhibitory to PMA- and ascorbate-stimulated latent HIV-1 reactivation; $\mathrm{Fe}^{3+}$ alone thus appears to reveal final antioxidant effects in this system, possibly due to its complex with EDTA. Evidently, the final outcome of chemical reactions and annihilations of individual compounds and free radicals, respectively, depends on many variables and can dynamically change in a biological system. Importantly, the concentrations of heme-degradation products used in this paper were comparable or lower than effective concentrations of heme arginate. On the other hand, effective concentrations of heme arginate are achievable in vivo (Tokola et al., 1986).

In ACH-2 cells, the effect of ascorbate or iron with ascorbate on induction of latent HIV expression was relatively lower at both RNA and protein levels than the effect of HA. Indeed, HA serves as a source of both iron and hemin. Heme similarly to iron generates ROS by Fenton reaction (Shibahara, 2003), while hemin is known to regulate expression of various genes (Furuyama et al., 2007; Mense and Zhang, 2006). On the other hand, pretreatment with a CO-donor or 
bilirubin dose-dependently decreased p24 levels in ACH-2 cells, while the CO donor increased EGFP expression and bilirubin was ineffective in $\mathrm{H} 12$ cells. These differences may be attributable to a different intracellular redox milieu, possibly affected by a constitutive expression of HO- 1 in $\mathrm{H} 12$ cells (Shankaran et al., 2011). These results also suggest that the contribution of the individual heme-degradation products may vary in different cell types in vivo. In the first approach to verify the stimulatory effects of heme arginate we have intentionally used PBMC's as they are closer to the situation in vivo. Nevertheless, additional experiments on individual cell types, namely on isolated total and resting CD4+ cells, will better assess the magnitude of HA-stimulatory effects and help to delineate the underlying mechanisms.

HIV-1 replication and spread is closely connected with the induction of cell death and can be modulated by its onset (Cummins and Badley, 2013; Wang et al., 2011, 2016). While the general apoptosis due to toxicity of latency reversing agents is not desirable, elimination of the infected cells is a goal of all approaches aiming at curing HIV-1. Increased redox stress characterized by decreased levels of reduced glutathione is associated with HIV-1 replication (Pace and Leaf, 1995), while it was suggested as an approach to reactivate and kill latently infected cells by several authors (Iordanskiy and Kashanchi, 2016; Lewis et al., 2011; Shankaran et al., 2011). Importantly, central memory and transition memory T-cells, the main reservoir cells containing the latent HIV-1, were shown to be more susceptible to the redox stress and apoptosis (Chirullo et al., 2013).

HIV/AIDS, similarly to other chronic infections, has been reported to lead to immune-mediated anemia of chronic disease, iron deficiency anemia or their combination (Kerkhoff and Lawn, 2015; Minchella et al., 2015), in which differential expression of hepcidin, hemojuvelin, ferroportin and other factors plays an important role (Drakesmith and Prentice, 2012; Krijt et al., 2004; Theurl et al., 2011; Xu et al., 2010). Consequently, iron supplements have often been administered. However, this can result in an increased labile iron pool and reactivation, expression and dissemination of HIV-1. In fact, it has been recognized that iron plays a critical role in several steps of HIV-1 replication (Nekhai et al., 2013) and its levels are modulated by most nonpathogenic simian immunodeficiency viruses (Koppensteiner et al., 2014). Several clinical studies also suggest that iron supplementation or hereditary defects leading to increased intracellular iron stores can fasten progression of HIV infection to AIDS in untreated patients (Gordeuk et al., 2001; McDermid et al., 2007; Rawat et al., 2009).

In our short-term experimental conditions, the stimulatory effects of heme arginate on HIV-expression clearly prevailed in ACH-2 and $\mathrm{H} 12$ cells as well as in HIV-infected PBMC's (Shankaran et al., 2011). On the other hand, heme arginate inhibits the acute HIV infection at the level of reverse transcription (Levere et al., 1991; Shankaran et al., 2011). Thus, the ability of heme arginate to stimulate a short-term reactivation of the latent HIV while inhibiting reverse transcription and further replication of the new virus progeny could make it a useful and safe agent in help to eliminate the HIV-1 latent pool in the presence of antiretroviral drugs.

Redox stress can affect epigenetic mechanisms regulating gene expression as well as activation of redox-sensitive transcription factors. Therefore, we propose a model in which heme arginate induces a redox stress leading to chromatin remodeling, binding of specific transcription factors to HIV-LTR and potentiation of HIV-1 expression induced by a PKC inducer. These results may constitute new direction in the latent HIV-1 reactivation and therapy.

Acknowledgements. We are grateful to Dr. Paula Pitha for kindly providing ACH-2 cells, Dr. Jana Blazkova for providing the H12 clone of Jurkat cells, and Dr. Ward De Spiegelaere for kind sugestions and protocols for qPCR and ddPCR. We thank Dr. Paula Pitha and Dr. Prem Ponka for helpful discussions, and Dr. Emanuel Necas and Dr. Josef Bodor for reading the manuscript and comments. We thank Monika Kaplanova for technical assistance. The work of P.S. and M.M. was performed in partial fulfillment of the requirements for Ph.D. degree at the 1st Medical Faculty, Charles University. The work was supported by the Grant Agency of the Ministry of Health of the Czech Republic (project No. NT/14135-3), by Charles University (project No. PRVOUK-P24/LF1/3), by the project BIOCEV"Biotechnology and Biomedicine Centre of the Academy of Sciences and Charles University in Vestec" (CZ.1.05/1.1.00/02.0109) from the European Regional Development Fund, and by the Ministry of Education of the Czech Republic-National Sustainability Program II, Project BIOCEV-FAR No. LQ1604.

\section{References}

Argyris EG, Vanderkooi JM, Paterson Y (2001): Mutagenesis of key residues identifies the connection subdomain of HIV-1 reverse transcriptase as the site of inhibition by heme. Eur. J. Biochem. 268, 925-931. https://doi.org/10.1046/j.14321327.2001.01944.X

Best B (2014): General AntiOxidant Actions. http://www.benbest. com/nutrceut/AntiOxidants.html\#radicals

Blazkova J, Trejbalova K, Gondois-Rey F, Halfon P, Philibert P, Guiguen A, Verdin E, Olive D, Van Lint C, Hejnar J, Hirsch I (2009): CpG methylation controls reactivation of HIV from latency. PLoS Pathog. 5, e1000554. https:// doi.org/10.1371/journal.ppat.1000554

Chirullo B, Sgarbanti R, Limongi D, Shytaj IL, Alvarez D, Das B, Boe A, DaFonseca S, Chomont N, Liotta L, Petricoin EI, Norelli S, Pelosi E, Garaci E, Savarino A, Palamara AT (2013): A candidate anti-HIV reservoir compound, auranofin, exerts a selective 'anti-memory' effect by exploiting the baseline oxidative status of lymphocytes. Cell. Death Dis. 4, e944. https://doi.org/10.1038/cddis.2013.473 
Clouse KA, Powell D, Washington I, Poli G, Strebel K, Farrar W, Barstad P, Kovacs J, Fauci, AS, Folks TM (1989): Monokine regulation of human immunodeficiency virus-1 expression in a chronically infected human $\mathrm{T}$ cell clone. J. Immunol. 142, 431-438.

Cummins NW, Badley AD (2013): Anti-apoptotic mechanisms of HIV: lessons and novel approaches to curing HIV. Cell. Mol. Life Sci. 70, 3355-3363. https://doi.org/10.1007/ s00018-012-1239-3

Drakesmith, H, Prentice AM (2012): Hepcidin and the iron-infection axis. Science 338, 768-72. https://doi.org/10.1126/ science. 1224577

Emiliani S, Van Lint C, Fischle W, Paras P, Jr., Ott M, Brady J, Verdin E (1996): A point mutation in the HIV-1 Tat responsive element is associated with postintegration latency. Proc. Natl. Acad. Sci. USA 93, 6377-6381. https://doi. org/10.1073/pnas.93.13.6377

Furuyama K, Kaneko K, Vargas PD (2007): Heme as a magnificent molecule with multiple missions: heme determines its own fate and governs cellular homeostasis. Tohoku J. Exp. Med. 213, 1-16. https://doi.org/10.1620/tjem.213.1

Gatignol A (2007): Transcription of HIV: Tat and cellular chromatin. Adv. Pharmacol. 55, 137-159. https://doi.org/10.1016/ S1054-3589(07)55004-0

Gordeuk VR, Delanghe JR, Langlois MR, Boelaert JR (2001): Iron status and the outcome of HIV infection: an overview. J. Clin. Virol. 20, 111-115. https://doi.org/10.1016/S13866532(00)00134-7

Harakeh S, Jariwalla RJ (1997): NF-kappa B-independent suppression of HIV expression by ascorbic acid. AIDS Res. Hum. Retroviruses 13, 235-239. https://doi.org/10.1089/ aid.1997.13.235

Harlow E, Lane D (1988): Immunoblotting. In Harlow E, Lane,D (Eds): Antibodies: A Laboratory Manual. Cold Spring Harbor Laboratory Press, New York, 471-510.

Hermes-Lima M, Ponka P, Schulman HM (2000): The iron chelator pyridoxal isonicotinoyl hydrazone (PIH) and its analogues prevent damage to 2-deoxyribose mediated by ferric iron plus ascorbate. Biochim. Biophys. Acta 1523, 154-160. https://doi.org/10.1016/S0304-4165(00)00115-X

Holden NS, Squires PE, Kaur M, Bland R, Jones CE, Newton R (2008): Phorbol ester-stimulated NF-kappaB-dependent transcription: roles for isoforms of novel protein kinase C. Cell Signal 20, 1338-1348. https://doi.org/10.1016/j. cellsig.2008.03.001

Iordanskiy S, Kashanchi F (2016): Potential of Radiation-Induced Cellular Stress for Reactivation of Latent HIV-1 and Killing of Infected Cells. AIDS Res. Hum. Retroviruses 32, 120-124. https://doi.org/10.1089/aid.2016.0006

Jordan A, Bisgrove D, Verdin E (2003): HIV reproducibly establishes a latent infection after acute infection of $\mathrm{T}$ cells in vitro. EMBO J. 22, 1868-1877. https://doi.org/10.1093/ emboj/cdg188

Jordan A, Defechereux P, Verdin E (2001): The site of HIV-1 integration in the human genome determines basal transcriptional activity and response to Tat transactivation. EMBO J. 20, 1726-1738. https://doi.org/10.1093/ emboj/20.7.1726
Kennedy KA, Sandiford SD, Skerjanc IS, Li SS (2012): Reactive oxygen species and the neuronal fate. Cell. Mol. Life Sci. 69, 215-221. https://doi.org/10.1007/s00018-011-0807-2

Kerkhoff AD, Lawn SD (2015): Iron replacement therapy and anemia associated with chronic infectious diseases in sub-Saharan Africa. Clin. Infect. Dis. 60, 1438-1439. https://doi.org/10.1093/cid/civ063

Kiselinova M, Pasternak AO, De Spiegelaere W, Vogelaers D, Berkhout B, Vandekerckhove L (2014): Comparison of droplet digital PCR and seminested real-time PCR for quantification of cell-associated HIV-1 RNA. PLoS One 9, e85999. https://doi.org/10.1371/journal. pone.0085999

Koppensteiner H, Hohne K, Gondim MV, Gobert FX, Widder M, Gundlach S, Heigele A, Kirchhoff F, Winkler M, Benaroch P, Schindler M (2014): Lentiviral Nef suppresses iron uptake in a strain specific manner through inhibition of Transferrin endocytosis. Retrovirology 11, 1. https://doi. org/10.1186/1742-4690-11-1

Krijt J, Vokurka M, Chang KT, Necas E (2004): Expression of Rgmc, the murine ortholog of hemojuvelin gene, is modulated by development and inflammation, but not by iron status or erythropoietin. Blood 104, 4308-4310. https://doi. org/10.1182/blood-2004-06-2422

Laemmli UK (1970): Cleavage of structural proteins during the assembly of the head of bacteriophage T4. Nature 227, 680-685. https://doi.org/10.1038/227680a 0

Levere RD, Gong YF, Kappas A, Bucher DJ, Wormser GP, Abraham NG (1991): Heme inhibits human immunodeficiency virus 1 replication in cell cultures and enhances the antiviral effect of zidovudine. Proc. Natl. Acad. Sci. USA 88, 1756-1759. https://doi.org/10.1073/pnas.88.5.1756

Lewis MG, DaFonseca S, Chomont N, Palamara AT, Tardugno M, Mai A, Collins M, Wagner WL, Yalley-Ogunro J, Greenhouse J, Chirullo B, Norelli S, Garaci E, Savarino A (2011): Gold drug auranofin restricts the viral reservoir in the monkey AIDS model and induces containment of viral load following ART suspension. AIDS 25, 1347-1356. https://doi.org/10.1097/QAD.0b013e328347bd77

McDermid, JM, Jaye A, Schim van der Loeff MF, Todd J, Bates C, Austin S, Jeffries D, Awasana AA, Whittlex AA, Prentice A (2007): Elevated iron status strongly predicts mortality in West African adults with HIV infection. J. Acquir. Immune Defic. Syndr. 46, 498-507. https://doi.org/10.1097/ QAI.0b013e31815b2d4b

Mense SM, Zhang L (2006): Heme: a versatile signaling molecule controlling the activities of diverse regulators ranging from transcription factors to MAP kinases. Cell Res 16, 681-692. https://doi.org/10.1038/sj.cr.7310086

Minchella PA, Armitage AE, Darboe B, Jallow MW, Drakesmith H, Jaye A, Prentice AM, McDermid JM (2015): Elevated Hepcidin is part of a complex relation that links mortality with iron homeostasis and anemia in men and women with HIV infection. J. Nutr. 145, 1194-1201. https://doi. org/10.3945/jn.114.203158

Nekhai S, Kumari N, Dhawan S (2013): Role of cellular iron and oxygen in the regulation of HIV-1 infection. Future Virol. 8, 301-311. https://doi.org/10.2217/fvl.13.6 
Otterbein LE, Soares MP, Yamashita K, Bach FH (2003): Heme oxygenase-1: unleashing the protective properties of heme. Trends Immunol. 24, 449-455. https://doi.org/10.1016/ S1471-4906(03)00181-9

Pace GW, Leaf CD (1995): The role of oxidative stress in HIV disease. Free Radic Biol Med 19, 523-528. https://doi. org/10.1016/0891-5849(95)00047-2

Pantano C, Reynaert NL, van der Vliet A, Janssen-Heininger YM (2006): Redox-sensitive kinases of the nuclear factorkappaB signaling pathway. Antioxid Redox Signal 8, 1791-806. https://doi.org/10.1089/ars.2006.8.1791

Pasternak AO, Adema KW, Bakker M, Jurriaans S, Berkhout B, Cornelissen M, Lukashov VV (2008): Highly sensitive methods based on seminested real-time reverse transcription-PCR for quantitation of human immunodeficiency virus type 1 unspliced and multiply spliced RNA and proviral DNA. J. Clin. Microbiol. 46, 2206-2211. https:// doi.org/10.1128/JCM.00055-08

Pyo CW, Yang YL, Yoo NK, Choi SY (2008): Reactive oxygen species activate HIV long terminal repeat via posttranslational control of NF-kappaB. Biochem. Biophys. Res. Commun. 376, 180-185. https://doi.org/10.1016/j. bbrc.2008.08.114

Rahman I, Marwick J, Kirkham P (2004): Redox modulation of chromatin remodeling: impact on histone acetylation and deacetylation, NF-kappaB and pro-inflammatory gene expression. Biochem. Pharmacol. 68, 1255-1267. https://doi.org/10.1016/j.bcp.2004.05.042

Rawat R, Humphrey JH, Ntozini R, Mutasa K, Iliff PJ, Stoltzfus RJ (2009): Elevated iron stores are associated with HIV disease severity and mortality among postpartum women in Zimbabwe. Public Health Nutr. 12, 1321-1329. https:// doi.org/10.1017/S136898000800390X

Sappey C, Boelaert JR, Legrand-Poels S, Forceille C, Favier A, Piette,J (1995): Iron chelation decreases NF-kappa B and HIV type 1 activation due to oxidative stress. AIDS Res. Hum. Retroviruses 11, 1049-1061. https://doi. org/10.1089/aid.1995.11.1049

Shankaran P, Vlkova L, Liskova J, Melkova Z (2011): Heme arginate potentiates latent HIV-1 reactivation while inhibiting the acute infection. Antiviral Res. 92, 434-446. https://doi. org/10.1016/j.antiviral.2011.09.011

Sheftel AD, Kim SF, Ponka P (2007): Non-heme induction of heme oxygenase-1 does not alter cellular iron metabolism. J. Biol. Chem. 282, 10480-10486. https://doi.org/10.1074/ ibc.M700240200
Shibahara S (2003): The heme oxygenase dilemma in cellular homeostasis: new insights for the feedback regulation of heme catabolism. Tohoku J. Exp. Med. 200, 167-186. https://doi.org/10.1620/tjem.200.167

Soe-Lin S, Sheftel AD, Wasyluk B, Ponka P (2008): Nramp1 equips macrophages for efficient iron recycling. Exp. Hematol. 36, 929-937. https://doi.org/10.1016/j. exphem.2008.02.013

Theurl I, Schroll A, Nairz M, Seifert M, Theurl M, Sonnweber T, Kulaksiz H, Weiss G (2011): Pathways for the regulation of hepcidin expression in anemia of chronic disease and iron deficiency anemia in vivo. Haematologica 96, 1761-1769. https://doi.org/10.3324/haematol.2011.048926

Tokola O, Tenhunen R, Volin L, Mustajoki P (1986): Pharmacokinetics of intravenously administered haem arginate. $\mathrm{Br}$. J. Clin. Pharmacol. 22, 331-335. https://doi.org/10.1111/ j.1365-2125.1986.tb02895.x

Venkatachari NJ, Zerbato JM, Jain S, Mancini AE, Chattopadhyay A, Sluis-Cremer N, Bar-Joseph Z, Ayyavoo V (2015): Temporal transcriptional response to latency reversing agents identifies specific factors regulating HIV-1 viral transcriptional switch. Retrovirology 12, 85. https://doi. org/10.1186/s12977-015-0211-3

Wang X, Ragupathy V, Zhao J, Hewlett I (2011): Molecules from apoptotic pathways modulate HIV-1 replication in Jurkat cells. Biochem. Biophys. Res. Commun. 414, 20-24. https://doi.org/10.1016/j.bbrc.2011.09.007

Wang X, Mbondji-Wonje C, Zhao J, Hewlett I (2016): IL-1beta and IL-18 inhibition of HIV-1 replication in Jurkat cells and PBMCs. Biochem. Biophys. Res. Commun. 473, 926-930. https://doi.org/10.1016/j.bbrc.2016.03.153

Xu M, Kashanchi F, Foster A, Rotimi J, Turner W, Gordeuk VR, Nekhai, S (2010): Hepcidin induces HIV-1 transcription inhibited by ferroportin. Retrovirology 7, 104. https://doi. org/10.1186/1742-4690-7-104

Yara S, Lavoie JC, Beaulieu,JF, Delvin E, Amre D, Marcil V, Seidman E, Levy E (2013): Iron-ascorbate-mediated lipid peroxidation causes epigenetic changes in the antioxidant defense in intestinal epithelial cells: impact on inflammation. PLoS One 8, e63456. https://doi.org/10.1371/journal. pone. 0063456

Zhang AS, Canonne-Hergaux F, Gruenheid S, Gros P, Ponka P (2008): Use of Nramp2-transfected Chinese hamster ovary cells and reticulocytes from $\mathrm{mk} / \mathrm{mk}$ mice to study iron transport mechanisms. Exp. Hematol. 36, 1227-1235. https://doi.org/10.1016/j.exphem.2008.04.014 